\title{
CYP2C19*4 Allele
}

National Cancer Institute

\section{Source}

National Cancer Institute. CYP2C19*4 Allele. NCI Thesaurus. Code C45608.

Human CYP2C19*4 allele is located within 10q24.1-q24.3 and is approximately $90 \mathrm{~kb}$ in length. This allele, a variant form of the CYP2C19 wild-type allele, does not encode a cytochrome P450 2C19 protein. The CYP2C19*4 allele exhibits a clinically-relevant SNP (c. $1 \mathrm{~A}>\mathrm{G}$ ) in the initiation codon that prevents translation of a protein product. Individuals who are heterozygous for this allele display a poor metabolizer phenotype. 